\title{
System of Continuous Improvement for a Cooperative Organization in Southern
}

\author{
Brazil \\ Sistema de Melhoria Contínua para uma Organização Cooperativa no Sull do Brasil \\ Sistema de Mejora Continua para una Organización Cooperativa en el Sur de Brasil
}

Received: 04/16/2021 | Reviewed: 04/23/2021 | Accept: 04/27/2021 | Published: 05/12/2021

\author{
Berenice Santini \\ ORCID: https://orcid.org/0000-0002-5300-8917 \\ Federal University of Santa Maria, Brazil \\ E-mail: bsantini35@gmail.com \\ Geovana Marla Pinheiro \\ ORCID: https://orcid.org/0000-0002-0452-4624 \\ Federal University of Santa Maria, Brazil \\ E-mail: gemarlapinheiro@gmail.com \\ Gilmar Jorge Wakulicz \\ ORCID: https://orcid.org/ 0000-0001-7564-2030 \\ Federal University of Santa Maria, Brazil \\ E-mail: gilmarwakulicz@politecnico.ufsm.br \\ Érica Santini de Lima \\ ORCID: https://orcid.org/0000-0002-7752-9565 \\ Federal University of Santa Maria, Brazil \\ E-mail: ericasantini92@hotmail.com
}

\begin{abstract}
Quality management requires from organizations more than knowledge and practices about tools and more than tradition and commitment to quality. It requires a system of continuous improvement which, although it can be guided by formal instruments (standards, models), must be structured based on the application of theoretical knowledge to the reality of each organization. This study aimed to suggest a system of continuous improvement suitable to the operations of a cooperative organization in the agricultural sector, located in the south of Brazil. The exploratory and descriptive study used interviews, on-site observation and document analysis. As a result, we suggest a continuous improvement system based on the PDCA cycle (Plan, Do, Check, Act), with quality tools associated with each stage, with emphasis on the planning stage, which requires more decisions than the others. In addition, it is suggested to intensify the training of employees and review the criteria for setting goals, in order to create conditions to organically integrate a set of elements capable of effectively contributing to the continuous improvement of the studied organization's processes.
\end{abstract}

Keywords: Quality management; Continuous improvement; Cooperative organization.

\section{Resumo}

A gestão da qualidade exige das organizações mais do que conhecimentos e práticas sobre ferramentas e mais do que tradição e comprometimento com a qualidade. É necessário um sistema de melhoria contínua que, embora possa ser balizado por instrumentos formais (normas, modelos), deve ser estruturado com base na aplicação do conhecimento teórico à realidade de cada organização. Este estudo teve como objetivo sugerir um sistema de melhoria contínua adequado às operações de uma organização cooperativa do ramo agropecuário, situada no sul do Brasil. $\mathrm{O}$ estudo exploratório e descritivo utilizou entrevistas, observação in loco e análise documental. Como resultado, sugere-se um sistema de melhoria contínua baseado no ciclo PDCA (Planejar, Fazer, Verificar, Agir), com ferramentas de qualidade associadas a cada etapa, com destaque para a etapa de planejamento, que requer mais decisões do que as demais. Além disso, sugere-se intensificar o treinamento dos colaboradores e revisar os critérios de definição de metas, de forma a criar condições para integrar organicamente um conjunto de elementos capazes de contribuir efetivamente para a melhoria contínua dos processos da organização estudada.

Palavras-chave: Gestão da qualidade; Melhoria contínua; Organização cooperativa.

\section{Resumen}

La gestión de la calidad requiere de las organizaciones más que conocimientos y prácticas sobre herramientas y más que tradición y compromiso con la calidad. Es necesario un sistema de mejora continua que, si bien puede guiarse por instrumentos formales (estándares, modelos), debe estructurarse en base a la aplicación de los conocimientos teóricos a la realidad de cada organización. Este estudio tuvo como objetivo sugerir un sistema de mejora continua adecuado a 
las operaciones de una organización cooperativa en el sector agrícola, ubicada en el sur de Brasil. El estudio exploratorio y descriptivo utilizó entrevistas, observación in situ y análisis documental. Como resultado, sugerimos un sistema de mejora continua basado en el ciclo PDCA (Planificar, Hacer, Verificar, Actuar), con herramientas de calidad asociadas a cada etapa, con énfasis en la etapa de planificación, que requiere más decisiones que las demás. Además, se sugiere intensificar la formación de los empleados y revisar los criterios de fijación de metas, con el fin de crear las condiciones para integrar orgánicamente un conjunto de elementos capaces de contribuir eficazmente a la mejora continua de los procesos de la organización estudiada.

Palabras clave: Gestión de la calidad; Mejora continua; Organización cooperativa.

\section{Introduction}

Quality, over the last decades, has become one of the most discussed themes by organizations and, due to globalization, it started to be evaluated based on international standards, requiring systematic production structures for standardization, registration and, mainly, the use of tools in quality management. Often, the competitiveness of companies depends on certifications, in both national and international markets. (Mello \& Gibbert, 2017, p. 102).

To achieve the levels of quality necessary for the current competitive context, a revolution in the organization's administrative processes is necessary. An organization must be prepared to absorb, quickly and satisfactorily, the social, technological and economic changes of the environment in which it is inserted. In this scenario, the competition is not restricted to the local scope, but reaches products from all over the world. (Bertolino et al., 2010, p. 11).

Globalization has raised market competition on an international scale, increasingly demanding from organizations the need for continuous improvement in their processes, in order to achieve quality. Thus, continuous improvement has become of great importance for attracting new customers, through reduction of errors, greater product quality and also compliance with the deadlines of each final product. Thus, it is necessary to adopt a process of improvements that is appropriate to its performance objectives, eliminating losses in the process, reducing costs and increasing product quality.

Orofino (2009, p. 67 apud Silva et al., 2017, p. 2), states that:

The continuous improvement applied to processes aims to eliminate the cause of any error, based on its identification by the process control mechanisms. This makes quality no longer an option, as it becomes a synonym for survival, being not only the characteristic of a product and / or service, but also the total satisfaction of customers' needs and expectations, becoming a part of providing the service, as well as the product, assuming continuous improvement as a philosophy to be followed by organizations.

Organizations in Brazil recognize the need to develop a system of continuous improvement as an essential element of quality management and have been following this path for some decades. In cooperatives, the creation of the Cooperative Management Development Program (PDGC), which works on the Governance and Management axes, was created recently, in 2013, inspired by the excellence criteria of the National Quality Foundation (FNQ), which exists since 1991. (SESCOOP, 2016).

In the food sector, quality management involves the need to implement the Good Manufacturing Practices (GMP) program, which implies developing standard procedures and maintaining certain standards in the food manufacturing process. (Machado, 2015). It can be said that alignment and control are considerable and important components for quality, but achieving quality management necessarily involves the implementation of a system of continuous improvement. The Cotrisel cooperative, with its seven units in the state of RS, completed the first cycle of implantation of GMP in the municipality of Restinga Sêca a few years ago. Aware of the need to stay on the path of quality management, the cooperative's management group has already internalized the philosophy of continuous improvement and works with this focus, although it does not have a systematic mechanism for it. From dialogues with the management team, the following question arose: what would the structure of a continuous improvement system for Restinga Sêca Cotrisel unit's operations be like? In this sense, with the 
objective to suggest elements for a continuous improvement system suitable for the cooperative's productive operations, actions that resulted in this work were taken.

This research was carried out with the support of Cooperativa Cotrisel's managers, at the Restinga Sêca unit, which has industrial facilities for processing rice. The following sections provide some theoretical elements on quality management, the methodology, data analysis, as well as discussions and final considerations.

\section{Literature Review}

The following section presents some theoretical bases on Quality Management Systems (QMS), and more specifically on continuous improvement (PDCA) and HACCP (Hazard Analysis and Critical Control Points), which will allow the analysis of the information collected in the empirical phase of the study.

\subsection{Quality Management and Continuous Improvement}

According to Deming (1990), the beneficial effects occur in a chain when the company's focus is on quality first. Therefore, the company and/or organization must present a general and constant concern with quality at all levels and sectors. Quality management can be defined as the set of actions planned and executed throughout the production cycle (suppliers and customers), in order to guarantee the required and planned quality for the product, at the lowest possible cost. (Toledo et al., 2014).

Organizations have started their actions related to quality by practicing the so-called quality control. However, this notion of control has evolved into a vision of a dynamic system, capable of covering all sectors of the organization, directly or indirectly, with the aim of contributing to the improvement and guarantee of product quality and safety. (Bertolino, 2010). Thus, so that organizations and/or companies can face the current demands of those who buy and consume their products, it is necessary (and essential) that they develop, improve and constantly perfect the processes used in the elaboration of these products, in the way how the processes are conceived, executed, controlled and perfected, in a constant and uninterrupted cycle of growth and improvement. (Ballestero-Alvarez, 2012).

For Toledo et al. (2014), continuous improvement includes adding value to the customer through the development and improvement of new or existing products and processes, seeking to reduce the number of defects and increase productivity. Continuous improvement seeks to improve equipment, materials, staff utilization and production methods through the application of suggestions and ideas from the work team members. In order to be practiced in organizations, the philosophy of continuous improvement needs methods and tools that disseminate its practice to everyone involved.

According to Ueno (2017), continuous improvement considers it important that the management system processes are planned, executed and continuously reassessed and improved, like a PDCA cycle. This process is an essential factor to increase the organization's competitiveness in the corporate world and to meet the constant needs of customer satisfaction increase, internal costs reduction, productivity increase and reactions to changes in the market in which the organization operates. However, the Shewart method was only popularized by Deming, in the 1950s, when he applied the cycle to his work developed in Japan, through which the so-called PDCA cycle became known worldwide. (Melo, 2009).

There are many tools that can be used in a quality management context in order to promote the continuous improvement. According to Silva et al., 2020; Lobo, 2020; FNQ, 2019; Toledo et al., 2014 and Paladini, 2012, some of them are brainstorming, Ishikawa diagram, flowchart, $5 \mathrm{~S}$, GUT matrix (gravity, urgency, trend), 5W1H, training, Analysis of the Method and Effect of Failures (FMEA), checklist; Statistical Process Control (SPC); Quality Function Deployment (QFD), pareto's chart, histogram, poka-yoke; Servqual; Six Sigma and Times Quality. Some of these are statistics tools. "The use of statistical tools by companies is associated with the view that, by identifying and removing the causes of problems, greater 
quality and productivity are obtained", to which is added that the use of specific and graphic techniques produces better results than of unstructured analysis processes. (Toledo et al., 2014, p.195). According to Lobo, Limeira and Marques (2015), these tools have specific emphasis, which can refer to a practical analysis of the production process to, for example, determine predictions about its development; or analyze the actions of competitors in the same market range; or even determine how to best serve a group of consumers.

For Housel (2012), a team is a group of people working collaboratively to achieve the same goal. Collaboration indicates a joint effort, especially in intellectual capacities. A team works properly when all its members cooperate, trust each other and plan together so that their goals become a reality. Teamwork is certainly not a new concept; in fact, a small group of people working together for mutual benefit is the oldest type of existing social organization, dating from the cave era, when they formed groups to increase their chances of survival. According to Chaves (2019), a team is formed by people from the same or related areas who develop continuous improvement and innovation activities in a conscious, committed and systematic way. Continuous activity and managerial monitoring allow these teams to mature and gradually achieve autonomy.

\subsection{The Path to Quality Management in Agricultural Branch Cooperatives: GMP and HACCP}

The food industry has encountered ever greater challenges, precisely because its business involves improving the quality of food, which includes regulatory, consumer and market requirements, with the objective of producing safe food, and at the same time, bringing commercial competitive advantages. It is known that "cooperativism is summed up in a philosophy that transforms the world into a fairer, more balanced place and provides opportunities for all" (Maffini, Wakulicz and Alberti, 2020 , p. 2) and that the values and principles of cooperatives presuppose an emphasis on valuing people (OCB, 2020). Hence the assumption that these organizations find it less difficult to provide good health and safety conditions for their employees, care for the environment and quality of their products and services, when compared to other organizational types.

Cotrisel managers recognize that there are more than one possibilities of certifiable quality management systems that could apply to the cooperative. The main ones are probably the systems based on ISO 9001 and ISO 22000 rules, of which integrated implementation is possible and productive (Lima, 2021). But the employee responsible for quality believes that the most likely path to be taken if this cooperative were to aim for quality system certification would be, in addition to the GMP that the cooperative already has, the implementation of the HACCP program, and then the Food Safety Management System (FSMS) according to NBR 22000 (Figure 1).

Figure 1. Structure of a Food Safety Management System compatible with Cotrisel's nature.

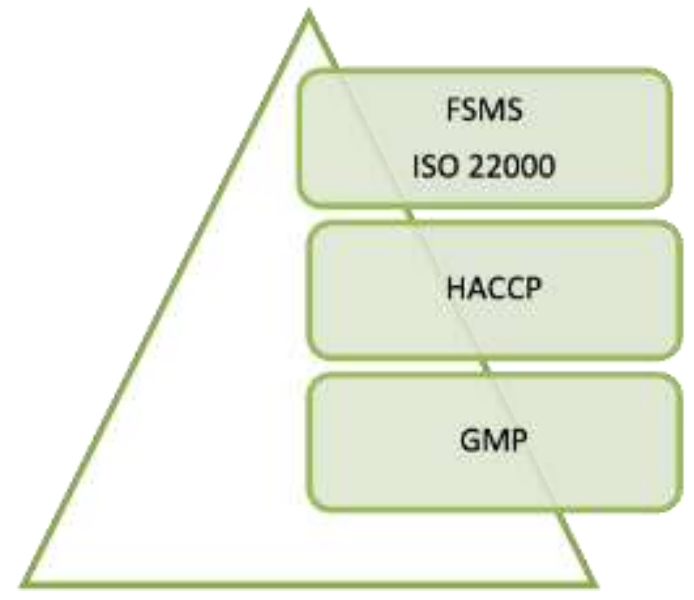

Source: Adapted from Santini et al. (2019). 
In Figure 1, a pyramid whose peak is a quality management system (in this case, the system guided by ISO 22000) is based on the GMP program, which plays this role by standardizing procedures and requiring systematic records of processes data, essential for rational decision making.

Good Manufacturing Practices are a set of guidelines and rules for the correct handling of products, from raw materials to the final product, that seek to ensure the safety of what is produced by the organization. (Bertolino, 2010).

Machado et al. (2015) recognizes GMP as a requirement of current legislation and as part of the quality assurance programs for the final product. An organization that applies GMP by developing more POPs (Standard Operating Procedure) than required by current legislation demonstrates familiarity with the organization of work, with setting and meeting standards, and is supposedly predisposed to meet the requisites required by a system quality.

The HACCP system (Hazard Analysis and Critical Control Points) is a scientifically based management tool used to ensure effective control of hazards in a preventive manner. It is a system that identifies, evaluates and controls hazards that are not significant for food safety. (Gava; Silva; Frias; 2008).

In summary, the HACCP system has the following foundation: if there is a possibility of dangers in a given food, it is known that this risk is real, whether they are biological, chemical, physical or in regards of quality (in the case of the Distribution sector), and that risk can be eliminated, reduced or controled. (Assis, 2013).

When marketing products, it is understood that consolidated customers are those who are satisfied, since they buy the product they liked again. Therefore, customer satisfaction is a direct function of product quality. Considering that the quality of the product is not consistent in the long run if it is not obtained from the quality of the process, the secret lies in understanding and controlling the stages of the product's manufacturing processes. (Bertolino, 2010).

According to Bertolino (2010), every organization has numerous process flows that are repeated daily. Knowing, analyzing and planning the best functioning of these flows will result in more stable and safe processes, which, of course, will generate more stable and safe products. Therefore, the routine of these processes must be managed, and that can be done through actions and checks so that each employee assumes responsibility in fulfilling the obligations conferred on each individual and organization. This can be done more effectively using the PDCA cycle, also known as the Deming cycle, which was developed by Shewhart and widely disseminated by Deming.

The acronym PDCA stands for Plan, Do, Check and Action, which means that, in management activities, everything needs to be planned, executed, verified and, when necessary, corrected or improved. Quality assurance actions organized in the PDCA cycle will form what is called a quality management system. (Bertolino, 2010).

Lobo (2020, p.49) recognizes that the PDCA cycle or cycle of continuous improvement, as it is also known, aims to identify and organize the activities of a problem solving process in order to effectively guarantee the development of a planned activity. The disordered growth, combined with the lack of planning and definition of goals, means that the company does not have a solid base and goes through seasonal situations. The correct use of this tool allows the company to always grow with a solid base, promoting continuous process improvement.

Next, understand the PDCA phases (Lopes; Alves; 2020):

a) Plan: planning, setting goals, specifying methods. Definition of the objective: the basis for any planning is to have defined the company's objective, that is, where it intends to be in ten years, for example. Definition of goals: after defining the objective, goals must be established to achieve it. The best way to set a goal is to ask the questions: is it measurable? Attainable? Relevant? What is the time limit? Is it specific?

b) Do: consists of training and carrying out the work.

c) Check: it's the verification of the results obtained.

d) Act: it's the corrective action to improve or maintain the process. 
Continuous improvement is a necessary element for HACCP, as the established procedures must detail: parameters and criteria to be met; monitoring program of parameters and criteria; corrective actions in case of detection of deviation from the established criterion; registration of the data obtained to ensure the traceability of the procedure's conditions of development; verification of the effectiveness of the procedure (internal supervision); internal, outsourced and governmental inspection; sample collection and analysis program; equipment calibration program, among others. The purpose of the verification is the certification of the procedure and its continuous improvement. (EMBRAPA, 2004).

\section{Methodology}

This research is classified as exploratory and descriptive, and its objective is to provide greater familiarity with the problem, with a view to making it more explicit or constituting hypotheses. (GIL, 2002). In general, exploratory research is carried out with the aim of providing an approximate overview of a given fact. Especially when the chosen theme is little explored, it aims to provide more information on the subject to be investigated, enabling its definition and delineation. (GIL, 2008).

Exploratory research has flexible planning, which allows the studying of the subject from different angles and aspects, and it usually involves bibliographic survey, interviews with people who have had practical experiences with the researched problem and analysis of examples that encourage its understanding. (Prodanov; Freitas, 2013).

The study took place at the Restinga Sêca unit of Cotrisel Cooperative, in the South of Brazil, that will be referred as Cotrisel only. It is considered the most modern in industrial structure among the seven units of the cooperative situated in this country. The unit is organized into sectors, which are: Administrative and Specialized Service in Safety Engineering and Occupational Medicine, Soy, Production (receiving and storage), Industrial Sector (processing, packaging and shipping), Quality Control (Good Manufacturing Practices and Industrial Laboratory), Technical Department (receiving laboratory and technical responsibility for storage) and Maintenance (mechanical, electrical, civil and general services). The focus of this research are Production, Industrial Sector, Quality Control and Technical Department, which are the most familiar with the philosophy of continuous improvement.

The main technique carried out to access data was interviewing, which is usually a flexible and open mean of data collection. Furthermore, from questions and answers, "communication and the construction of meanings can be achieved simultaneously" (Sampieri, Collado \& Lucio, 2013, p. 425). The interviews were semi-structured because their basic structure was previously defined, using open-ended questions and stimuli to encourage the interviewee to discuss in depth and to emphasize aspects that are most relevant to them (Olsen, 2018). Pre and post interviews, the researchers were able to carry out most of the documents' analysis and on-site observation in order to provide greater understanding of the research object.

In view of the theoretical concepts addressed in the literature review, an interview protocol was structured to guide the search for information in the exploratory research. Table 1 shows these elements and the techniques, used in this research: 
Table 1. Research protocol - interview guide.

\begin{tabular}{|c|c|c|c|}
\hline \multicolumn{4}{|c|}{ PDCA CYCLE METODOLOGY } \\
\hline \multicolumn{3}{|c|}{ STEPS } & QUESTIONS \\
\hline $\mathbf{P}$ & (1) & $\begin{array}{c}\text { Discover the root } \\
\text { causes of the } \\
\text { problem } \\
\text { Draw up an action } \\
\text { plan to block root } \\
\text { causes }\end{array}$ & $\begin{array}{l}\text { In any work process, it is common for minor problems to occur, which are } \\
\text { dealt with momentarily by the person who noticed it, without significantly } \\
\text { altering the process. But sometimes the problem is more relevant to the point } \\
\text { that it deserves a greater investigation effort. What are the characteristics of a } \\
\text { problem that makes you mobilize to investigate? Has the process flowchart } \\
\text { itself (its steps) been previously designed? } \\
\text { Based on the process flow (designed or not), do you already know where the } \\
\text { critical points are, those that need to be more controlled and that can more } \\
\text { easily generate problems? What types of problems have you encountered in } \\
\text { this process? } \\
\text { When setting out to investigate a problem: } \\
\text { How do you proceed? (Who participates? How do you organize yourselves? } \\
\text { What do you use in terms of data and tools?) Do you normally already have a } \\
\text { database that can be used to investigate the problem? } \\
\text { What are the difficulties that you observe to arrive at the root causes of the } \\
\text { problems? } \\
\text { Is there a methodology, a sequence of actions that you already take to discover } \\
\text { actions in mind for that? What quality actions or tools do you think would be } \\
\text { useful? (Name a few) } \\
\text { This study results in an improvement plan. Is it formalized / registered? Is } \\
\text { there a standard for plans? } \\
\text { How is it done? Do you usually set goals for improvement? By whom? }\end{array}$ \\
\hline $\mathbf{D}$ & EXECUTION & $\begin{array}{l}\text { Act in accordance } \\
\text { with the action } \\
\text { plan }\end{array}$ & $\begin{array}{c}\text { Who implements the corrective actions provided for in the plan? How is this } \\
\text { implantation? Does it involve training the personnel responsible for } \\
\text { implementing it? How is it done? }\end{array}$ \\
\hline $\mathbf{C}$ & CHECKING & $\begin{array}{l}\text { Confirm the } \\
\text { effectiveness of } \\
\text { blocking the } \\
\text { causes }\end{array}$ & $\begin{array}{l}\text { After corrective actions have been taken, how do you know if there have been } \\
\text { improvements in the process? } \\
\text { How do you record these improvements? Are there control indicators for } \\
\text { improvements? Are they general or created for each case? Could you } \\
\text { exemplify? }\end{array}$ \\
\hline $\mathbf{A}$ & STANDARDIZATION & $\begin{array}{l}\text { Prevent the } \\
\text { problem from } \\
\text { reappearing }\end{array}$ & $\begin{array}{l}\text { When an action plan for improvement is implemented and the results are } \\
\text { positive, how do you maintain this improvement, that is, to ensure that the } \\
\text { problem will not return? And is there any kind of indicator to measure this? }\end{array}$ \\
\hline
\end{tabular}

Source: Authors (2021).

The research protocol (Table 1) was structured based on the PDCA phases. Each step was accompanied by a brief definition (third column) and questions (fourth column). The questions elaborated sought to provoke reflections and deepen the respondents' answers about each phase of the cycle.

Data were obtained from the industrial director, as from the employee responsible for quality in the unit, the agronomist and the food technologist responsible for issues related to food quality in all units. It was 20 hours of data collection (approximately). The direct semi-structured interviews carried out in person during the three technical-managerial visits to Cotrisel, in May and June 2019 and July 2020. Document analysis and on-site observation were carried out before and after the interviews. In addition, a team of managers of the cooperative was at the Polytechnic College (UFSM) giving an 
explanation to teachers and students about the GMP of the Restinga Sêca unit. Besides everything, the data was being supplemented by phone and WhatsApp over time.

\section{Results and Discussion}

Data were obtained through various collection strategies, so that they can be analyzed sequentially and crosswise. The results are organized according to the PDCA cycle order of elements, as presented in the interview protocol. The analysis of these results made it possible to formulate the proposal for a continuous improvement methodology for Cotrisel, presented in the last section.

\subsection{Cotrisel Practices Aligned with Continuous Improvement Systems}

Cotrisel's Restinga Sêca unit already has a culture of continuous improvement rooted in the way of thinking and acting of the production and the GMP program leaders. These people demonstrate understanding of the importance of having data to support decisions that seek improvements, which denotes recognition by the scientific method of investigating causes of problems. However, the improvement processes carried out do not follow any methodology in practice, neither with regard to the choice of the problem, nor in the definition of goals, nor in the method itself (steps), nor in the definition of the improvement team.

According to director Pozzebon (2020), the cooperative uses the PDCA tool in a more pragmatic way, that is, motivations or concerns are related to action or efficiency, and not to the standardization of the process itself.

Although the philosophy of continuous improvement seems to be present among the cooperative's employees in general, not everyone has basic training to be able to work with a systematization tool that formalizes the continuous improvement processes, such as the PDCA. And there is an evident concern of the production director with the possibility that the implementation of a formal system may bring more negative than positive aspects in Cotrisel's search for Quality Management. The director also stated that, at the moment, it's impossible to teach all employees how to use this tool, so the quality sector ends up providing training in the area and using the tools in the most appropriate way in its own sector. (Pozzebon, 2020).

But the dilemma becomes clear between, on the one hand, seeking to systematize improvement and, on the other, recognizing the difficulties of this path. In one of his statements, the director commented that due to the lack of formality of the PDCA, there are several flaws in the process. The philosophy of the PDCA cycle facilitates the visualization of what was and what was not accomplished. Thus, there is an interest in formalizing the use of the process as a whole, however, this requires time and dedication for the cooperative to adapt to these changes.

Undoubtedly, increasing the involvement of staff in the improvement processes is considered important and has been a concern of the cooperative's production managers. In this sense, the director states that the use of GMP already promotes good results. The following section presents the GMP program in the context of continuous improvement and quality management.

\subsubsection{The Good Manufacturing Practice Program (GMP)}

Cotrisel's Restinga Sêca unit is an organization committed to seeking the quality of its products and processes. In all contacts made, the employees demonstrated to understand the importance of quality for the cooperative's performance and consequently for the results of its members. This perception is represented in the statement by Lemos (2020), Food Technologist, who says:

Good Manufacturing Practices correspond to operational, structural and documentary issues, taking into account 
sanitary and layout constructions that favor control of cross contamination. The GMP program is based on Standard Operating Procedures (POP's), which deal with: Integrated Pest Management (IPM), especially focused on those that can act as vectors of contamination; systematic controls for glass and rigid plastics; allergen control plan; operational cleaning and sanitation procedures; waste management procedures to prevent cross-contamination; care for the health and hygiene of food handlers and maintenance of equipment used to guarantee valid process results or to demonstrate results related to CCPs (critical control points). Thus, GMP well contemplate our need to avoid manufacturing problems. (Lemos, 2020).

It should be noted that, although GMP may have a preventive character, they form the basis of the pyramid whose peak is Quality Management and play, predominantly, the role of generators of procedures, which in turn generate results (data collected from the processes) that should be used as a basis for establishing improvement goals to be achieved through the "spin" of the PDCA cycle.

Pozzebon (2020) states that, although POPs are in fact applied directly in the operation, the effectiveness of formalizing procedures is recognized by management and employees. He said that due to the good results obtained from its use, the trend is that the number of POP's will be increased over time.

The effectiveness of using POP's is demonstrated by the stability of production processes, which allows robust data to be collected for monitoring. Pozzebon (2020) states that these data serve as a basis for studies to improve processes (equipment, technologies, investments, etc.). But he recognizes that having POP's and recording data systematically is not enough for the complete functionality of the PDCA method.

\subsubsection{Elements of the PDCA Cycle Practiced by Cotrisel}

The data collected show that improvement projects are practiced, however the interviewees themselves recognize that there is no formal system for this, that is, formal guidance and documentation, neither of the improvement, nor of the steps that led to it. They also recognize that after the implementation of GMP, such formalization would be an important step to continue on the path of Quality Management.

The improvement system has become necessary for any organization. We can say that, in order for the cooperative to investigate a problem, it prioritizes the characteristics of gravity, recurrence, potential for damage to the brand, loss of productivity and waste/cost generated. With this information, a cooperative can better visualize and proceed with the investigation process and thus be able to generate improvements in the system. (Pozzebon, 2020).

Models of improvement projects should suggest compliance with the steps of the scientific method of investigation, which are represented by the PDCA steps. Below are the perceptions of how each of these steps is applied (or not) at Cotrisel.

\subsubsection{Plan}

According to Lobo (2020), improvement planning involves four substeps: identifying the problem, observing the problem, analyzing the problem and formulating the action plan. In the interviews, some aspects of planning or the lack of it were observed. In general, Pozzebon (2020) stated that "The cooperative's improvement plans have not yet been formalized", which was especially observed in the production sectors and directly related to it. Still in a general context comes the statement of the employee responsible for quality: "We can say that the most common problem encountered by the cooperative is the difficulty in controlling pests. Other problems presented are those related to raw materials, like rice with high potential for defects, and those related to the production inputs being used in the process, such as packaging”. (Felix, 2020).

The quality of rice that the cooperative produces comes from the rural properties of the cooperative members. In this sense, the chief agronomist in the technical department who supports the producers stated that "the system adopted by the 
cooperative consists of working individually with these producers, without having a general plan, but there is a desire to implement a system that achieves the objectives and goals, thus achieving the desired results". (Tomazi, 2020). He acknowledges that there is no systematic procedure for setting goals in the technical department, a fact that was also observed in most sectors surveyed. On the other hand, Pozzebon's (2020) statement that "there are goals established by the quality control sector working group" suggests a leadership position in this sector in terms of promoting improvements in the cooperative.

These elements indicate that, in fact, there is an awareness of the importance of widespread improvement at the managerial level and there is a management group that takes on the responsibility of taking the initiative to carry out improvement projects. In general, managers seek to be aware of the facts and to identify problems at any time and under any circumstances. For this, the cooperative has a well-structured database, mostly provided by the records of the GMP program, which is already used when investigating problems. Through this, an investigation request is made to the employees involved in the process, which is usually coordinated by the manager of the investigated unit and makes it possible to obtain all necessary information to diagnose the problem presented in the sector. Pozzebon (2020) understands that the relevant information is normally screened and, if it is not successful, it starts with an on-site investigation done by a "trained team". He understands that the production tracking process is well defined and detailed, and that the cooperative has no greater difficulty in reaching the causes of the problems.

However, no clear systematic procedure for the problem identification substep (including setting improvement targets) was observed. The absence of this procedure indicates that the cooperative may be expending efforts to solve problems that are not the most relevant, as there is no technical criterion for prioritizing these or establishing improvement goals.

Regarding the observation and analysis of problems, Pozzebon (2020) states that the cooperative has the process flowchart already designed and defined, making the critical points of the process, those that can more easily generate problems during the process, be known with greater precision and control. In fact, the macro flow of the process is very well defined in the documentation of the GMP program. But for it to be used in the PDCA observation substep, it would need to be opened in microflows, involving the discussion of the details of the processes carried out in each of the "sectors" of production.

With the action plan formulation substep, the absence of standardized documentary records is presented once again. And this substep is especially important to ensure that the execution stage takes place as effectively as possible and that it promotes the dissemination of the philosophy of continuous improvement, as it disseminates responsibilities of the improvement process.

\subsubsection{Do}

Although the cooperative does not have a formalized plan, the production director states that:

Corrective actions are implemented by people designated according to the necessary skills and competences, always involving managers and supervisors from the respective sector. We do not forgo outside help from outsourced companies. We acknowledge the importance of finding qualified people to give us adequate training to seek positive results for each action implemented in the system (Pozzebon, 2020).

Perhaps this implementation process could be more effective if employees in general participated more effectively in this execution, with more training. The production director commented on "the difficulty of training people". (Pozzebon, 2020). 


\subsubsection{Check}

There are no specific records for the improvement process, however, they follow the same sequence of routine records that already exist and are applied to each sector of the cooperative. (Pozzebon, 2020). As the problems found were verified through the POP's quality records, it would not be necessary to create further documentation to verify the improvements. The verification of improvements could be added to a quality record, which would be attached to POP's and, over time, all data could be compared.

\subsubsection{Act}

According to Pozzebon (2020), when the results are positive due to the implementation of an action plan for improvement, it is assimilated as a standard procedure, that is, it avoids new problems or even that an old problem returns. However, this "assimilation" to which he refers is limited to the skills, commitment and motivation of leaders. The lack of standardization of improvement processes represents an obstacle when it comes to reproducing the improvements achieved, an effect that expands as time passes. Since there is no standardization, there is no documentation. Thereby, the reproducibility of the good results obtained depends on the memories of the professionals who performed such actions.

\subsection{Proposal for an Improvement System Based on the PDCA Cycle}

After analyzing what Cotrisel already does and how it does it for the sake of improvement, it is suggested a system that addresses the weaknesses pointed out in the previous section. Therefore, it is proposed that Cotrisel's improvement system be based on the PDCA cycle and formalized/documented, including the Planning, Execution, Verification and Corrective Action/Standardization steps. At each of these stages, it is suggested to associate quality tools that can facilitate the conduct of the process and make its results more effective.

The unit's management group must continue to define which priority projects are to be developed in the cooperative. However, it is suggested that they maintain regular meetings for data analysis, identification and prioritization of problems. On these occasions, they must have quality records, SPC records (Statistical Process Control) and all other documents that contain data from all sectors related to production. This will help to avoid bias in the evaluation of situations that will be considered or not problems and in the relevance that will be attributed to them.

For each improvement project that the management group determines the execution, an improvement team that will have the participation of one or two managers and other employees involved in the process under study (three or four recommended) must be formed. The work of this team should follow the scientific method, represented by the stages of the PDCA cycle. Each team formed must build a work schedule for their project. Initially, they must be led by the manager, but it is recommended that the manager(s) observes and encourage the emergence of other leaders in the improvement groups.

From the universe of tools available in the literature (Silva et al., 2020; Lobo, 2020; FNQ, 2019; Toledo et al., 2014, Paladini, 2012), some are already used by Cotrisel and others are suggested here, as they are somehow appropriate, according to the arguments that accompany. They are indicated in the diagram in Figure 2. 
Figure 2. Suggestions of tools to be used in the PDCA cycle of improvements.

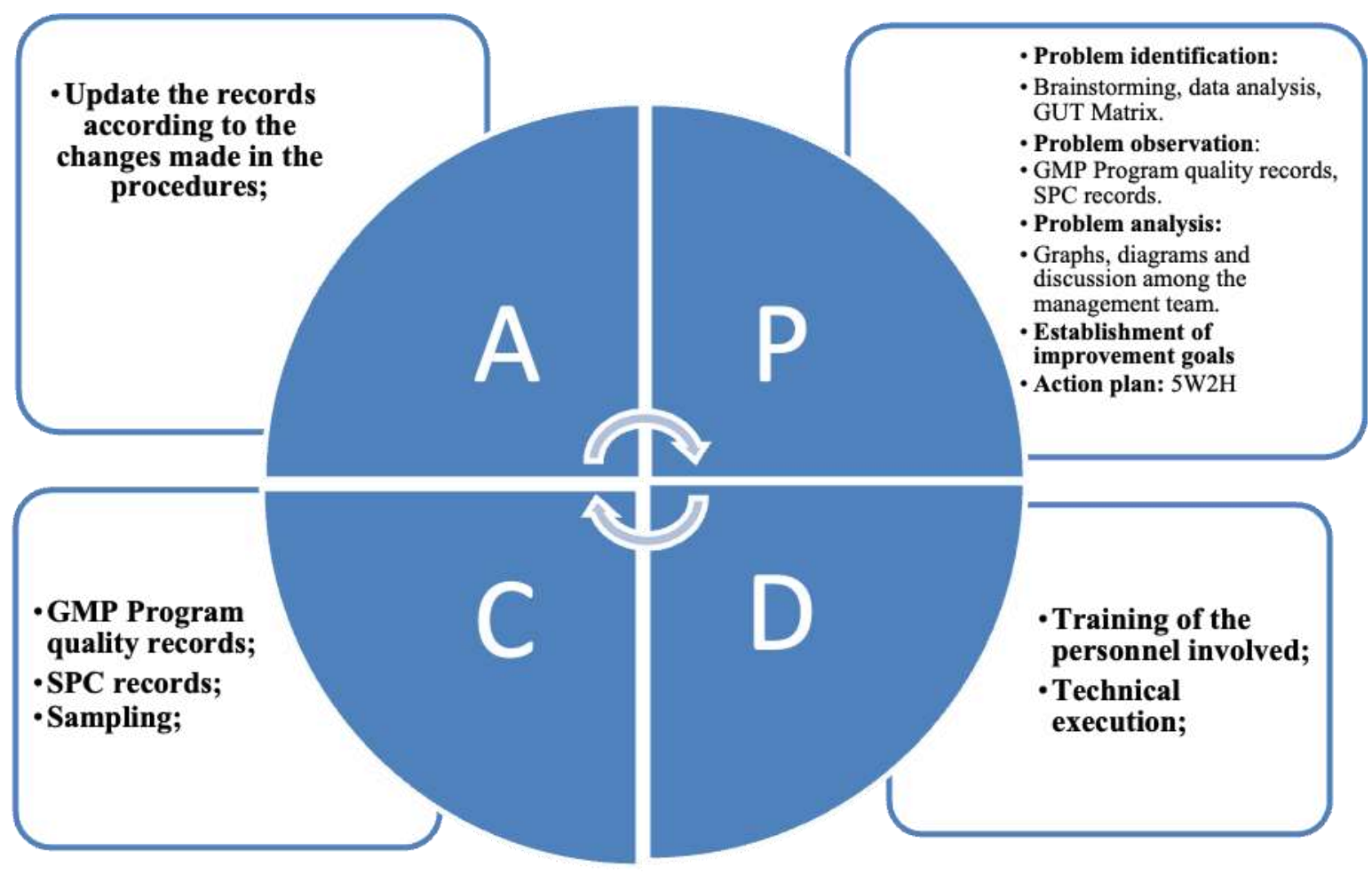

Source: Authors (2021).

The suggestions of tools made in Figure 2 took into account their applicability and simplicity of understanding, which facilitates its dissemination among employees (Lobo, 2020; Toledo et al., 2014). This is explained in detail below.

\subsubsection{Plan.}

\subsubsection{Problem identification}

The problem must be identified by the management team. The identification should start by examining data reports in the most rational way possible. These reports are commonly referred to in the literature as data sheets or checklists. They are forms designed to facilitate the registration and analysis of the data obtained in a data collection (Possarle, 2014).

Once a list of problems has been raised, it is necessary to have criteria to define an order of priority. Here the suggestion is to use a Prioritization Matrix, such as the GUT Matrix or similar. The GUT matrix is used to assist managers in the task of prioritizing problems, it is a tool for analyzing priorities based on severity (G), urgency (U) and trend (T). (FNQ, 2019).

At any point in the problem identification substep, it may be interesting to make room for the diversity of thoughts of the people in the group, in order to obtain and consider diversified points of view, covering the greatest number of possibilities, both of problems and of their effects (severity, urgency). At such times, it is suggested that the management team uses Brainstorming. (Lucinda, 2010). This tool encourages the practice of starting from a broad spectrum of ideas, where all possible ideas will have their turn to appear, before focusing on one or a few, contributing to the rationality in the different stages of team decisions.

\subsubsection{Problem observation}

Observation takes place by monitoring the data that refer to the problem, usually through recent past records. These 
records can be the GMP Program Quality Records, SPC records or others that are already in use. But if necessary, the team must build new data verification sheets and wait for some time to obtain the registration of new data.

It is also considered that, although the recorded data are essential for the observation of the problem, on-site observation and all other ways of obtaining knowledge about the problem by the components of the improvement team should be used here in this substep.

\subsubsection{Problem analysis}

To obtain a more accurate analysis, it is suggested the use of graphs, diagrams and also the discussion among the improvement team members. The graphs are like sampling points from measurements of a given quality characteristic. The use of graphics aims to contribute to their visualization, facilitating the perception of their behavior, their magnitude, relationships and trends.

Thus, it is suggested to use all simple graphs and others classified as quality tools, such as Pareto diagram, dispersion diagrams, cause and effect diagrams, control graphs and others. The analysis of control charts, for example, can point out discrepant points or trends and inform whether or not the process is under statistical control, being useful for monitoring the variability and for assessing the stability of a process.

The problem analysis sub-step ends with the establishment of improvement goals. A target for each problem, which must be quantitative and very well dimensioned. Once the previous substeps have been completed, each team will have the knowledge to establish an improvement goal that is both feasible (not so difficult to achieve) and challenging (not so easy to achieve).

\subsubsection{Action plan}

It is suggested that the action plans of the improvement teams be organized using the $5 \mathrm{~W} 2 \mathrm{H}$ tool. For Seleme and Stadler (2012), the use of such a tool allows a running process to be divided into stages, structured from the questions, in order to be found as failures that prevent the proper completion of the process. The result of its application is not a clear indication of the faults, but its exposure for a more precise analysis.

The formal use of action plans by improvement teams will facilitate the definition of effective tasks and monitoring in a visual, agile and simple way. The plans contain a list of actions that need to be taken to solve the problem, each followed by arguments about why the action should be taken, how it will be done, who will be responsible for it, how much it will cost and when it will be completed. These action plans can be represented on paper, electronically, in a physical mural etc. The important thing is that everyone on the team can follow the development of all actions, regardless of who is responsible for them. This sharing of information tends to promote greater team integration and lead to better results.

\subsection{Do}

At this stage of the PDCA, each step of the action plan must be carried out, as established in the plan. Here, the responsibility of the improvement team to conduct the execution is highlighted, as well as the great importance of training for the team and for other employees whose daily performance will be impacted by this process. It is important that employees are aware of the problem, the action plan, as well as the improvement team and their responsibilities. Likewise, all members of the organization must understand that the improvement projects are strategic for the sector and for the organization and duly supported by the board. This will avoid conflicts and will tend to strengthen the environment of collaboration and alignment of all towards the improvements that are sought. 


\subsection{Check}

The step of verifying improvements consists of monitoring changes in the processes that result from the execution of the improvement actions. The verification must be done continuously, during and after the implementation of the action plan, in view of the goal established in the analysis (planning) substep.

This monitoring should, as far as possible, be based on the same data recording forms used in the previous steps by the management and improvement teams. Thus, the quality records of the GMP program, SPC records and all other records used in the sectors must be used again. Only if specific records have been created as a result of the improvement project, they should certainly be used for verification as well.

The sampling tool are techniques that will allow the cooperative to obtain representative information about effectiveness, that is, it's the study of the various types of errors that may occur during its execution.

\subsection{Act}

This step begins with the verification of the results of the action plan execution, in comparison with the improvement goal. If the goal has been achieved, it's started the consolidation of the implementation of these actions that "went well". Thus, the improvement will be used on a daily basis, reaching a level that will be established as a standard.

If the goal has not been achieved, the improvement team can establish a new action with a view to improving results towards the goal. Often, a small additional effort in the last stage of the improvement cycle values all the effort previously expended and provides the achievement of the goal. This complementary action is called corrective action.

It is very important that all changes in the way of doing the process that were implemented by the actions of the improvement project are effectively incorporated by it. The team will only have closed the improvement process after this standardization, which needs to reach the process documentation, modifying it. This is the guarantee that the improvement will be incorporated into the process, adding more quality to it. And this pattern will become the reference for the identification of new opportunities for improvement and new turns in the PDCA cycle, constituting the culture of gradual and continuous improvement.

\section{Final Considerations}

In view of the content explored, the present study aimed to suggest, based on the improvement practices that the cooperative already has and with the support of literature, a model of continuous improvement suitable for Cotrisel's operations.

First of all, it is necessary to recognize that Cotrisel has a qualified management team that is attentive to trends in its technical area and in the area of strategic management. It was observed that the cooperative's managers, especially those linked to production and quality, have the mindset of continuous improvement, which is undoubtedly a very important point and favorable to the adoption of an improvement system at Cotrisel's Restinga Sêca unit. The analyses and observations during the research reinforced the initial perception that Cotrisel's moment is favorable to the implementation of a formal system of continuous improvement.

It could be observed that the cooperative's improvement actions are coordinated and carried out essentially by the management team and that the observation and data analysis substeps are often made possible by the GMP program documents. In fact, the practice of GMP and SPC are the cooperative's strengths on this path towards continuous improvement and quality management. SPC, applied to the industrial sector, allows observing the variability of the process and monitoring its behavior in relation to the control limits. It brings the idea of failure prevention to its core, highlighting the proactive stance of managing industrial production in the cooperative. In other sectors, this preventive stance can also be perceived, but its 
systematization is not so evident because the practices are not so structured with tools or methods that can make them more explicit. In other words, improvements are often made in the cooperative, but they do not follow the necessary formalization so that they have the essential continuity to become part of the organizational culture.

It is suggested that Cotrisel's system of continuous improvement be formalized and based on the PDCA cycle, with the involvement of the largest possible number of employees in the improvement teams. It is suggested that quality tools be an effective part of this system, in greater numbers in the planning stage, which requires more decisions than the other PDCA stages. The suggested tools are specified in section 4.2. In addition, special care is suggested with regard to the establishment of improvement goals, in the problem analysis substep, during planning.

For this, it is suggested that the data analysis (documents and reports) be made in systematic meetings of the management group, and from that it be determined which deviations from quality should be the work subject for an improvement project. Then, the management group must deal with the formation of a team to act in each of these improvement projects. In order to choose which problems (or opportunities for improvement) to prioritize, it is suggested that the management group previously define general criteria based on its quality standards for products and processes.

The suggestions made rely on the commitment and engagement of the team as a whole, and for that it is essential to intensify training and education for quality. This change process can be slow, gradual and involve high extra costs. It is understood that the systematization of continuous improvement contributes to the strengthening of Cotrisel cooperative values and principles. For example, the democracy exercised within the improvement teams, the education exercised in the actions of training and educating for quality, in the learning of tools and in the awareness of what genuinely represents a philosophy of continuous improvement in people's work and life.

Due to its qualitative nature, the results of this work should not be directly applied to other realities but can be used as a start to incentive similar studies in cooperatives of the same branch or not, with similar processes. Other than that, it would be interesting to continue this research testing this PDCA model in different Cotrisel's sectors, in order to understand its applicability to different internal environments and the viability to elaborate adaptations to the model to use it on the same organization.

Lastly, the authors recognize and thank the strong support from the cooperative's management group, that made it possible to accomplish the objectives of this research. It is a greater motivation to continue dialoguing with them in the search for knowledge for both the academy and the productive environment.

\section{References}

Assis, L. (2013). Alimentos Seguros: ferramentas para gestão e controle da produção e distribuição. (2nd ed.). Senac Nacional.

Bertolino, M. T. (2010). Gerenciamento da qualidade na indústria alimentícia: ênfase na segurança dos alimentos. 320 p.

Ballestero-Alvarez, M. E. (2012). Gestão de qualidade, produção e operações. (2nd ed.). Atlas.

Chaves, N. M. D. (2019). Equipes de Melhoria Contínua. Caderno de campo: método e ferramentas para equipes de melhoria. Falconi.

Deming, W. E. (1990). Qualidade: a revolução da administração. Marques Saraiva.

EMBRAPA. (2004). Manual de Boas Práticas Agropecuárias e Sistema APPCC. 123 p.

Felix, A. (2020). Entrevista concedida a Geovana Marla Pinheiro.

FNQ. (2019). \#45 Guia prático: 5 melhores ferramentas de gestão para você utilizar na empresa. https://fnq.org.br/comunidade/e-book-45-guia-pratico-de-5melhores-ferramentas-de-gestao-para-voce-utilizar-na-empresa

Gava, A. J., Silva, C. A. B., \& Frias, J. R. G. (2008). Tecnologia de Alimentos: princípios e aplicações. Nobel.

Gil, A. C. (2002). Como elaborar projetos de pesquisa. (4th ed.). Atlas.

Gil, A. C. (2008). Métodos e técnicas de pesquisa social. (6th ed.). Atlas. 
Housel, D. J. \& Zanella, M. M. (2012). Equipes: gerenciamento para o sucesso. Cengage Learning.

Machado, R. L. P.; Dutra, A. S. \& Pinto, M. S. V. (2015). Boas práticas de fabricação. Embrapa Agroindústria de Alimentos. https://ainfo.cnptia.embrapa.br/digital/bitstream/item/132846/1/DOC-120.pdf.

Melo, M. C. (2009). Gestão da Qualidade Total - Ciclo PDCA: Estudo de Caso em uma Indústria Frigorífica no município de Pimenta Bueno. Trabalho de Conclusão de Curso. Universidade Federal de Rondônia.

Mello, F. R. \& Gibbert, L. (2017). Alimentos - Controle de qualidade 2. Qualidade dos produtos, Sagah.

Lemos, B. V. (2020). Entrevista concedida a Geovana Marla Pinheiro.

Lima, C. D. Leite, G. F.; Alves, R. R.; Ribeiro, A. O.; Martins, A. L. S. \& Oliveira, R. J. (2021). Proposta de integração do Sistema de Gestão de Qualidade (SGQ) e de Gestão de Segurança Alimentar (SGSA) em empresas de embalagens metálicas para a implementação da norma ISSO 22000:2018. Research, Society and Development, 10 (1), 1-17. doi:10.33448/rsd-v10i1.11597

Lopes, Beatriz C. \& Alves, J. P. (2020). Ciclo PDCA aplicado na indústria do pescado. Braz. J. Anim. Environ. Res., 3 (3), 1370-1379.

Lobo, R. N. (2020). Gestão da Qualidade. (2th. ed). Érica, 2020.

Lobo, R. N.; Limeira, E. T. N. P. \& Marques, R. N. (2015) Controle da Qualidade: princípios, inspeção e ferramentas de apoio na produção de vestuário. Érica.

Lucinda, M. A. (2010). Qualidade: fundamentos e práticas para cursos de graduação. Brasport.

Maffini, M.; Wakulicz, G. J. \& Alberti, R. (2020). Análise da fidelidade dos associados em uma cooperativa central do Rio Grande do Sul através do modelo sueco. Research, Society and Development, 9 (12), 1-39. 10.33448/rsd-v9i12.9200

Morais, L. A.; Siqueira, E. S. \& Silva, R. A. Gestão e responsabilidade ambiental nas práticas de uma cooperativa de agricultura familiar: a percepção de cooperados. (2020). Research Society and Development, 9(6), 1-26. 10.33448/rsd-v9i6.3552

Paladini, E. P. (2012). Gestão da qualidade: teoria e prática. (3th ed). Atlas.

Olsen, W. (2015). Coleta de dados: Debates e métodos fundamentais em pesquisa social. Penso. 231p.

Organização das Cooperativas do Brasil (OCB). (2020). https://www.ocb.org.br.

Possarle, R. (2014). Ferramentas da Qualidade. SENAI-SP, Editora.

Pozzebon, G. M. (2020). Entrevista concedida a Geovana Marla Pinheiro.

Prodanov, C. C. \& Freitas, E. C. de (2013). Metodologia do Trabalho Científico: métodos e técnicas da pesquisa e do trabalho acadêmico. (2th. ed). Novo Hamburgo: Feevale.

Sampieri, S.; Collado, C. F.; Lucio, M. D. P. B. (2013). Metodologia de pesquisa. (5th. ed). Penso. 624p.

Santini, B; Lemos, B. V.; Oliveira, D. \& Pinheiro, G. M. (2019). Contribuição das boas práticas de fabricação para a gestão da qualidade na cooperativa Cotrisel. IX SINGESCOOP;

Seleme, R, \& Stadler, H. (2012). Controle da Qualidade - As Ferramentas Essenciais. (2th. ed). IBPEX.

SESCOOP (Serviço Nacional de Aprendizagem do Cooperativismo). (2016). Manual de Autoavaliação da Gestão e Implementação de Melhorias (Série Caminhos para a Excelência). Brasília: FNQ - Fundação Nacional da Qualidade: Organização das Cooperativas Brasileiras - OCB.

Silva, C. O. et al. (2017). A utilização do método PDCA para melhoria dos processos: um estudo de caso no carregamento de navios. Revista Espacios, 38 (27), $9 \mathrm{p}$.

Silva, J. M.; Teles, G.; Lima, C. M. G.; Pimentel, T. C.; Santos Júnior, O. O.; Madrona, G. S.; (2020). Implementation of quality tools in a stuffed pasta industry. Research, Society and Development, 9 (8), 1-22. doi:10.33448/rsd-v9i8.5444

Toledo, J.C.; Borrás, M. A. A.; Mergulhão, R.C.; \& Mendes, G. H. S. (2014). Qualidade: Gestão e métodos. LTC.

Tomazi, M. (2020). Entrevista concedida a Geovana Marla Pinheiro.

Ueno, T. J. (2017). Gestão da Qualidade. SENAC. 